\title{
ON OSTROWSKI AND EULER-GRÜSS TYPE INEQUALITIES INVOLVING MEASURES
}

\author{
A. ČIVluaK, LJ. Dedić AND M. Matić
}

Abstract. Some generalizations of weighted Ostrowski and Euler-Grüss type inequalities are given by using general Euler identities involving real Borel measures.

Mathematics subject classification (2000): 26D15, 26D20, 26D99.

Key words and phrases: Ostrowski inequality, Grüss-type inequalities, real Borel measures.

\section{REFERENCES}

[1] A. ČIVLJAK, LJ. DEDIĆ AND M. Matić, On an integration-by-parts formula for measures, To appear (submitted to International Journal of Pure and Applied Mathematics).

[2] A. ČIVLJAK, LJ. Dedić AND M. Matić, Euler-Grüss type inequalities involving measures, To appear (submitted to Elsevier, JMAA, Nov 19, 2006).

[3] M. MatiĆ, J. PeČARIĆ AND N. UJEVIĆ, Generalizations of weighted version of Ostrowski's inequality and some related results, Journal of Inequalities and Applications, 2000, Vol. 5, pp. 639-666. 